\title{
The man created in God's image - spiritual axis of the world. Saint Gregory of Nyssa's theology
}

\author{
Fr. PhD. Florea STEFAN \\ Faculty of Theology and Sciences of Education, \\ Valahia University of Târgovişte \\ ROMANIA \\ E-mail: pr_floreastefan@yahoo.com
}

\begin{abstract}
Man has been created at the crossroads between the material and the spiritual things, being given the greatest honour among creatures, since he is the only one edified in God's image and likeness. With Saint Gregory, the image does not mean, as in Platonism, the rough analogy of the sensitive world in relation to the intelligible world, but participation, a communion, yet without supposing a transfer of substance. There are two levels of the image in his theology: Christ - Logos of the Father, archetypal image, on this level the image supposing the very communion of nature, the hypostatizing of the unique divine being, and man - image of the Logos, level on which the image supposes the ontological distinction, yet simultaneously, by its quality of direct image, of non-mediated reflection, is a faithful image, this image containing in itself precisely the promise of communion, though, by its character, it has to define the eternity of the distinction between created and uncreated.
\end{abstract}

Keywords: man; world; divine image; philosophy; Saint Gregory of Nyssa; holiness;

\section{INTRODUCTION}

Maybe the meeting between the Greek philosophy and the Christian theology has never been as harmonious as in Saint Gregory of Nyssa's work. Maybe in no other place, especially in ontology, has the Christian Revelation been so systematically structured using the scaffolding of the Greek thinking. In his relation on the Genesis, a series of stages of the creation act are revealed to us, stages supposed by its aim, which is the creation of man as a thinking being, edified in God's image and likeness.

\footnotetext{
"After the physical universe has been created, man did not appear immediately on earth; on the contrary, the speechless animals were created before him, and previous to them, the plants. By this order, I think the Scripture wanted to show to us that the vivifying power got mixed with the material nature in a certain order: first it put on the senseless ones, then it moved on to the sensitive beings and then it ascended to the thinking and speaking nature. Therefore, out of everything that exists in the world, a part is material and sensitive, and another one has the ability to think." 1
}

We can note how the creative process is thought by Saint Gregory of Nyssa according to logic of harmonization of the whole set, by the gradual constitution of the created, distinct orders, yet all bearing the same seal of creature. This distinction between the created orders actually permits their harmonization, yet it simultaneously imposes their

\footnotetext{
${ }^{1}$ Sf. Grigorie de Nyssa, Dialog despre suflet şi înviere, P.G. 46, 60 A-B
} 
hierarchic arrangement. The whole set is developed to attain an aim above this set, namely man. Therefore all the creation is thought in such a way as to be able to receive the one in whom the ineffable character of the divinity is fully reflected - man. The study of the ascendant stages of nature do not reveal to us only a necessary progress law, but also one of imperative foundation, in which each stage is the sine qua non condition of the next stage. The essential thing is the impossibility of the spirit's existence without the sensorial for the human condition: this determines the intertwinement of the eternity in the sphere of human spirituality.

"Man, supreme fruit of nature's ascent, has the duty of unifying it in his spirit and to bring it as a whole in front of God". "Through man flows a unique gift of the same value upon the whole creation. The body and the entire material world receive the spiritual reflection of the soul, becoming an image of the image." 2

Man is thus created and thought of, implicitly, in a double connection, namely both related with the cosmos (universe) and with the divinity. On the one hand, the harmony between man and universe, man being thought as a microcosm, as a whole, in whom the entire beauty of creation is reflected under the auspices of rationality, makes him an authentic master of the universe. On the other hand, man seen as a divine creation, makes of this feature a seal of divine saturated with the structured material of creation, giving way to the potentiality (latency) of building the integral likeness between the created and uncreated, but this should be enabled by creature's own freewill, otherwise the essential spirit of it, namely the freedom, would be obscured.

This double character of man, this position of his at the crossroads between the material and the spiritual things, offers two ways: the ascendant one, to the likeness, the ascent supposing to accurately follow the likeness to God, in other words, man's personal answer according to his edified nature, namely the plenary manifestation of the man in the universe, through which the creation meaning would be fully achieved (reached); the opposite way, the descendant one, opposition to likeness, concealment of the image and its plunge in the world's materiality, stepping against the human nature itself.

From the fall's relation we know which was the option, we fully note it in every action of our humanity. This is where man's tragic status comes from as a reality generated by his own freedom affirmation.

\section{MAN, THE ONE EDIFIED ACCORDING TO GOD'S LIKENESS}

The Holy Fathers think about the human being definition starting from two directions: on the one hand, from Revelation to the immediate reality, and on the other hand, from the immediate reality to the Revelation's meanings, Saint Gregory approaching in his writings both directions of thinking. This dialectic approach is possible because of mankind's nature itself:

\footnotetext{
"Man was the last one among creatures: not because he was to be thrown to the end of the line as an unvalued one, but because he was entitled, from the very first moment of his birth, to be an emperor ruling over his servants... God put in man's nature the mixed seeds of divine and human, so that he can taste from the happiness of both, namely the joy of being interconnected with Him, and also the laic pleasures, by his feeling that he is not apart from joys.",
}

\footnotetext{
${ }^{2}$ Hans Urs von Balthasar, Présence et Pensée..., p 34

${ }^{3}$ Sf. Grigorie de Nyssa, Despre facerea omului, P.G. 44, 133 A-B
} 
In conclusion, human being belongs to two realities, more or less naturally obvious, but simultaneously present, thus the possibility of the double approach in man's definition as being submitted to two different orders.

When we talk about the theologically ruled humanity, about what man should have been and is not exactly all the time, the direction is from Revelation to the immediate concreteness.

While, in the Old Testament, man was considered from the perspective of God's likeness, the theological context itself refusing the image of Christ, the New Testament Revelation will change the accent moving it on to the divine image. Saint Apostle Paul will have the mission of preaching Christ as image of God, according to the following: "The Son is the image of the invisible God, the firstborn over all creation, for in him all things were created." (Col. 1:15). Starting from here, the direction of a Pauline New Testament's anthropology will appear, according to which, man validates himself as an authentic man, only if he proves in himself the man par excellence, the heavenly man who is Jesus Christ, the Father's image, because our becoming into humanity imposes the attainment of "the measure of the stature of the fullness of Christ" (Ephes. 4:14).

The Holy Fathers' theology continued Saint Paul's way of thinking, connecting Saint Paul's theme "Jesus Christ - God's image" with the Genesis theme "Man - created in to God's image". Already in the writings of Iraeneus, Clement, Origen, Athanasius and Saint Gregory of Nyssa appears very clearly the idea that Jesus Christ represents God's image and man represents Jesus Christ's image, namely man is image of the Image, yet of the Archetype Image. "The firstborn over all creation is God's image... yet man is made in God's image." (Origen) And "in Christ's image; because this means in the image of the Creator" (Saint John Chrysostom)". This change of anthropological accent will be the mark of the new theology, of that theology based on the fullness of the Revelation which is Christ, and from this moment on, man's status will be thought of as essentially Christ-centered. ${ }^{4}$ Taking into account the Christological theology, the next step will be the anthropological definitions from this new perspective, which will be realized in analogical manner in their great majority, by means of man's reference to the archetype Christ. In this way, man's Christ-centered character will be revealed both by the image stamped upon his being, and where can we find the most pregnant image of the divinity in man if not in Jesus Christ, who restores the whole human nature bringing the image to completeness, and also by the rational and spiritual features by which man manifests himself in the created reality, always attracted by overcoming it in order to attain that asymptotic likeness.

\section{THE REFLECTION OF THE DIVINITY INTO THE HUMANITY}

Yet, in order to integrate our thinking in the authentic theology of the image, we need to understand what the image or the eikon for Saint Gregory of Nyssa represents. For the pagan thinking the image is considered either as a possession of something of the archetype of whose image is, as in the Stoic philosophy, or as a simple copy, a modeling of an absolutely different reality. In Plato's philosophy we had observed that the image is par excellence the idea of the thing, the paradigm, and the thing is that what it is, only to the extent to which it suggests the specific attributes of the paradigm, but the image will never partake of its paradigm, given the ontological separation supposed by the alterity of the two

${ }^{4}$ Panayotis Nellas, Omul - animal îndumnezeit, Deisis, Sibiu, 1994, p 7-9 
worlds; in Christian terms, the image will never reach the absolute likeness of its paradigm, given the ontological distinction that stands as separation in the absolute.

Let us analyse the evolution of the word "image" - EIK $\Omega \mathrm{N}$

- Plato: the word refers to the sensitive world in its connection with the intelligible world, it supposes an analogy between these two worlds, yet, the supposed analogy itself implies a relation of inferiority of the copy in relation to the original.

- Philo: the term will signify the very reality of the participation, being applied to the human Logos, Kosmos and Nous.

- with Saint Gregory, the meanings will be strictly of religious nature, though the term already has a long history in the Hellenistic thinking:

- applied to the Logos, as Saint Paul had done in Colossians 1: 15, it does not mean an incomplete participation, but the genuine relation of originating in a perfect identity of nature, here he refers about the Trinitarian meaning of the term;

- in a different sense, regarding man, his likeness with God is not realized by means of a cosmic intermediation, as in Philo's thinking, but man himself is image of God: "You have to understand how much honour you got from The One who created you. The sky was not edified as an image of God, nor was the Moon, the Sun, anything from all the things created by Him."

The second term: "likeness" - OMOI $\Omega \Sigma \mathrm{IN}$, what does it consist in? It is an authentic participation to all the attributes of God:

"The one created in God's image possesses the entire likeness of his archetype: he is spiritual like $\mathrm{He}$ is spiritual, he is incorporeal like He is incorporeal... The soul is like a living image participating to the archetype's dignity and name." "To be created in God's image means that a kingly dignity is offered to man by his creation, yet this dignity does not consist in the external attributes, but in virtue, in the happiness of immortality, in justice..." "This indescribable happiness according to virtue supposes purity, freedom from sinful passions, happiness, going away from the entire evil: these are what the likeness of God consists of."7

With Saint Gregory, the image does not mean, like in Platonism, the rough analogy of the palpable world in relation to the intelligible world, but. But, continuing Philo's thinking, it means participation, a communion, yet without supposing a transfer of substance. There are two levels of the image in his theology: Christ - Logos of the Father, archetypal image, on this level the image supposing the very communion of nature, the hypostatizing of the unique divine being, and man - image of the Logos, level on which the image supposes the ontological distinction, yet simultaneously, by its quality of direct image, of nonmediated reflection, it is faithful image, this image containing in itself precisely the promise of communion, though, by its character, it must emphasize the eternity of the distinction between created and uncreated. But, more than this, the image is the seal of the divinity upon the entire humanity, none of the individual hypostases being able to drain up (exhaust) the image. The pleroma (fullness) He has created was projected by a single action in existence, all together and not each hypostasis by a unique action. Still the pleroma is situated in the space and time where the life of the creation unfolds, where it develops until the moment it reaches the plenitude. ${ }^{8}$

The image, the face, with Saint Gregory, supposes the possibility of communion which the revealed likeness opens as a potentiality.

\footnotetext{
${ }^{5}$ Sf. Grigorie de Nyssa, Despre suflet şi înviere [Dialogue about soul and resurrection]P. G. 46, $41 \mathrm{C}$

${ }^{6} \mathrm{Sf}$. Grigorie de Nyssa, Despre suflet şi înviere [Dialogue about soul and resurrection] P. G. 44, 136 C-D

${ }^{7}$ Ibidem, 137 A-B

${ }^{8}$ A. G. Hamman, L'homme, image de Dieu, Desclée, Paris, 1987, p 214
} 
"The image represents a supernatural participation to God's holiness. The image refers to the intellectual life (nous) and to the spiritual life (pneuma), together forming human nature (physis) in the state he has been created. The somatic, psychic or animal life is a superadded accident" $"$.

We note especially at Saint Gregory a dynamic connotation introduced in the concept of image. It is the eternal attraction which he will manifest for the ascension towards likeness. It is the image's way of manifestation, the ceaseless drive towards reaching the likeness. Moreover, with Saint Gregory of Nyssa, the interpretation of the image sends directly to this communion potency, as it opens the way to a unification supported on the idea of the existence of a feature shared by both natures, this constituting the principle that justifies man's desiring God, as a natural aspiration of human nature towards what is characteristic to it, because it is specific of the human nature not to find fulfillment in the material world, but, by assuming this world and transfiguring it, his fulfillment being only the meeting with its identity from above:

\begin{abstract}
"The way the eye comes in communion with the light by means of the glow naturally existing inside it, attracting by means of this natural power planted in him, what is connatural with him, similarly it became necessary to mix the human nature with something connatural with the Divine, so that by means of this correspondence, the human nature may long for what it is intimately related with. This is what the word on the Creation of the World has shown by means of just one word, using a comprehensive expression and saying that man was created in God's image." 10
\end{abstract}

Thus, man's thirst for God becomes a natural feature, a deep reflection of what man is as such: image of his Creator.

\title{
3. THE ATTRIBUTES OF IMAGE: FREEDOM AND LOVE
}

God's image in man is considered by Saint Gregory the source of humanity, yet of that humanity born from above, able to reflect the celestial Man that Saint Paul the Apostle was talking about, because:

"The Creator, giving him the likeness of an archetype of a distinguished beauty, also explained on that occasion the precise destination for which he was brought to life, and He ordered then, according to the meaning of man's activity, that all man's aim is in connection with the divine will.",11

We will present below the attributes that make out of the image a source of divine fulfillment, mentioning that, for Saint Gregory of Nyssa, the human dignity resides precisely in the divine birth, in man's likeness with God:

\footnotetext{
"What does man's greatness consist in? Not in his likeness to the created world, but in the fact that he is made in the image of the nature who created him. ${ }^{12}$ "In his writing On Man's Creation, Saint Gregory turns his back on the Stoics' pantheism, refusing to define man from the perspective of his likeness to the universe. The thesis is unacceptable if we take into account that the creation is structured to glorify man, who is its king and its center, in charge with guiding all the creation to God. Man's greatness comes from the fact that he is image of God."13
}

\footnotetext{
${ }^{9}$ Alain Besançon, Imaginea interzisă, Humanitas, Bucureşti, 1996, p 107

${ }^{10}$ Sf. Grigorie de Nyssa, Marele Cuvânt Catehetic, P.G. 45, $21 \mathrm{C}$

${ }^{11}$ Sf. Grigorie de Nyssa, Despre facerea omului, P.G. 44, 136 A

${ }^{12}$ Ibidem, 16, 180A

${ }^{13}$ A. G. Hamman, L'homme, image de Dieu, Desclée, Paris, 1987, p 207
} 
Man is edified by the unification of two levels, but what is his law and, implicitly, his dignity is what connects him with the divinity, what stimulates his ascent. This is the source of the thinking of man, of the complete man, not of the one who has not reached the age of maturity in Christ. The way our Holy Father thinks the anthropological development of this chapter is the analogical one, relying on the possibility of drawing an analogy between the divine attributes and the human features, this opportunity being opened, as it was mentioned above, by the very meaning of the term "image".

In this context, maybe the first feature of the image is the incognoscibility:

\begin{abstract}
"Therefore, because one of the features considered to belong to the divine nature is the incomprehensibility of the being, necessarily in this, too, the image has the imitation of the archetype. Because the nature of the image could be comprehendible, but the prototype would be above comprehension, the contrariety of these qualities considered would demonstrate the illusory character of the image. But because the nature of our mind which is in the Creator's image, escapes our comprehension, it has an exact likeness to the superior one, marking by such an incognoscible character its incomprehensible nature."14 "The eikon is the fundamental gift of God through which and in which God completely (fully) gives Himself to the created humanity. Thus, the eikon contains all the divine attributes, all the divine gifts, its nature as energy, understanding by this the character of incomprehensibility character, not the one of infinity. The unfathomable mystery of the human soul is the reflection of the divine incomprehensibility." 15
\end{abstract}

While all that belongs to the created world can be rationally decrypted in their intimate parts precisely due to their intrinsic rationality, man, as bearer of the divine image, reveals himself as resembling the One, by this ineffable character. No one belonging to the rational world is able to decrypt His image. We are referring to image's features, to manifestations of it, which represent the decipherable aspects of the human being, still no rational type of cognition (knowledge) will be able to state what man is. Every time there will remain something, an indeterminable bit that will escape any reductionist rationalist exercise, and, hence, the unrepeatable character of the individual, who has his core in this incomprehensibility specific to the original image. No effort of our reason will ever be able to decipher it. This highlights an apophatic foundation of the human, about which we will talk in the same negative terms, specific of the divine being that is the source of this foundation. All that is in agreement with this world is rational, compliant to the being's reason, but those that are not in agreement with this world will not be able to subscribe to the comprehensible reasons of this world ether. Hence, perhaps the most powerful argument of man's divine origin.

It is necessary to mention here an anthropological explanation. Saint Gregory, when he speaks about man, uses two stages of the humanity, analyzing the standard man, the man before the fall, and the Man Christ, in opposition to the ordinary man. The standard man is seen through the perspective of the divine image connected to the materiality structure, and the real man is analyzed from the perspective of the divine image darkened in the same relation to the materiality. From here results the necessity to distinguish between what is and what should be. Moreover, we need to state that both the man before the Fall, and the man after the Fall, by his created human nature, are simultaneously material and spiritual, yet what has priority in the relation between the parts gives to man his character: either primordial is the emphasis on the image toward the likeness, or the emphasis of materiality becomes primordial, determining the image's occultation, though, in both cases, the essence

${ }^{14}$ Sf. Grigorie de Nyssa, Despre facerea omului [About man's creation], 11, P.G. 44, 156AB

${ }^{15}$ A. G. Hamman, L'homme, image de Dieu..., p 217 
of humanity is considered to be God's image, because, man, man as he should be, remains the Christ archetype, and the man per se becomes a man only to the extent to which he is centered in Christ, so to the extent to which the image occultation is dissipated. Saint Gregory of Nyssa states in this sense the differences between the two sides of humanity, yet without breaking the human as a whole:

\begin{abstract}
"What do we state here, in conclusion? That man, this thinking being is able to think and to know, but our human being can not be defined only by these notions, if we were to admit that anger and lust and sinful passions of this kind were inborn in us since the beginning. Because anger and lust are vices common both to the thinking and unthinking nature, it would not be wise to describe each of them, starting from features common to both natures. Yet what is superfluous in describing a thing, and which we have no need of, how could it have to be defining? This is the reason why in any definition are considered the specific features of the object that has to be defined. All the non-specific features and of a different nature than the object defined, are not considered in definition. On the other hand, all the researchers consider that the action of lust and anger is present in the whole world of unthinking beings. Common attributes are not the same with the specific ones. Especially, this means that we should not consider anger and lust among the feelings characterizing in the first place the human nature, but as we see functioning in us different parts of the body for touching, eating and growing, no one will deny because of them the above-mentioned definition of the soul, because the existence in the soul of certain attributes does not mean the inexistence in the body of those activities and parts of it; similarly, after somebody had observed that our human nature's tendencies to anger and lust do exist, he would unfairly be against the soul's definition, considering it incomplete. "16
\end{abstract}

Yet, if the essence of what humanity is escapes our reason, as the being of the divinity does, too, we should unravel the actions that activate this essence, those that are essential attributes of the divine image existing in man. All these attributes of the humanity as divine image, are in their first activation Jesus Christ's features, because $\mathrm{He}$ is the Archetype of the divine image, the divinity's fullness being settled in Him. Jesus Christ is par excellence Logos, simultaneously God's Logos and the creation's Logos, implicitly Logos of the Christ-centered man. In this manner, man reaches a double affirmation of his rationality, corresponding to his dual character: on the one hand, the materiality by which man gets integrated in the universe is a proof of the rational Christocentrism that marks the universe from the perspective of the creation's Logos, and, on the other hand, man is again Christocentric by his attribute of man edified according to God's image.

Talking about the two ways of defining humanity, only the revealed one can determine the character of image of:

\footnotetext{
"this rational and thinking being, man, piece of work and copy of the pure divine nature, that had neither in his nature, nor coexisting with him, at the moment of his first genesis, either the attraction to sinful passions or mortality. Because it would have been impossible to maintain the reason of the image, if the beauty reflected in the image had been contrary to the archetype" $" 17$.
}

Therefore, the rational nature that plainly distinguishes man from all the other beings is a divine mark. While all are edified according to rationality, only human nature is able of rational reflection, only man is able to know that he is beyond the instincts that make him a being that belongs to the universe. Saint Gregory of Nyssa states in this sense:

\footnotetext{
${ }^{16}$ Sf. Grigorie de Nyssa, Dialog despre suflet şi înviere, P.G. 46, 52C-53B

${ }^{17}$ Sf. Grigorie de Nyssa, Despre feciorie, P.G. 46, 369B- 376C
} 


\begin{abstract}
"we should take into account that in the divine Being and in our mind we meet something in common, because we note that we see both of them as being outside the circle of things that can be known by means of our senses." 18
\end{abstract}

In conclusion, if we take into account the ascendant theory, from the immediate reality to the revealed one, it can be determined only the alterity character of the human ration in connection with the being, but its divine origination can be only a supposition, not in any case a truth. What can validate this presumption, what can transform this opinion of man about himself in a truth is only the Revelation that unveils his origin.

In this sense, what consists as a source of the humanity, what makes man be the way he is, is precisely the divine image existing inside him, an image that makes the distinction between man and all the other creatures. The main feature of the distinction made is in the first place rationality. Though, relying on the affirmation of the same ontological scheme of integrality specific of Saint Gregory of Nyssa, this rationality does not exist as an unique mark of the humanity, being only one of the correlated attributes that define humanity from the perspective of the divine image, the Saint stating in this sense the following:

"The One Who edified man in His image planted in the nature of the one He created the seeds of all the goodness (virtues), so that none of these virtues creeps from the outside, but what we want is in our power, taking out as from a treasury, the good in our nature." 19

Hence, the image is valued as a source of all that is beneficial in man, as spring of all the good seeds (aspirations). Yet, the presence of the image as source of good things does not imply their unconditional activation. Man does not manifest himself as being kind in all his actions due to the fact that he is edified according to the divine image. Our author himself makes the distinction here, affirming "the seeds of all the goodness (virtues)" as a mark, not referring here to their manifestation. We should seize the implicit character of benefic potentiality that the presence of the divine image in man gives to him, and when we affirm potentiality, implicitly we affirm its activation only by means of the human free will, and not as a mechanistic obligation susceptible of annihilating the subject's freedom. Still, the affirmation of these distinctions between the bodily nature and the spiritual nature of man should not be thought of as generating an irreconcilable break between the pneumatic man and the carnal man, because man is pondered over as an integrality, as a unique individual that succeeds in integrating both of his natures, moreover, the integration of the carnal is specific of the good human nature, being even possible for him:

\footnotetext{
"If man was brought in the world to partake of the divine goods, it appears as necessary that just as he was edified, he is also able to partake of them." 20
}

Following the same scheme of the correlative terms, the rationality of the image brings with it man's status of king over the created world, as the Genesis states: "Let us make man in our image, after our likeness. And let them have dominion over the fish of the sea and over the birds of the heavens and over the livestock and over all the earth and over every creeping thing that creeps on the earth." (Genesis 1:26) And he is worthy of all this dominion as "the one who even from his birth moment ought to rule as a king over his servants." ${ }^{, 21}$ In this dominion over the entire creation we can see the attribute of Lord that

\footnotetext{
${ }^{18}$ Sf. Grigorie de Nyssa, Dialog despre suflet şi înviere, P.G. 46, 36A

${ }^{19}$ Sf. Grigorie de Nyssa, Despre Fericiri, P.G. 44, 1253D-1256A

${ }^{20}$ Sf. Grigorie de Nyssa, Marele Cuvânt Catehetic, P.G. 45, 21C;

${ }^{21}$ Sf. Grigorie de Nyssa, Despre facerea omului, P.G. 44, 133A;
} 
Jesus Christ Himself possesses and brings to completeness by assuming the fullness of the human nature, of that nature in which the entire cosmos is contained the way the microcosm reflects in itself all the attributes of the whole. This aspect is presented in a very modernistutilitarian way in the seventh book of On Man's Creation, where man's status of king over the created world is analyzed by developing the utility criterion which affirms that all the submissive creation is meant to fulfill man. From here comes a new manner of approach concerning the presence of man in the created world, on the one hand as a king, and on the other hand all the created beings being presented not only as submissive to man, but simultaneously as useful to him, man being considered from the perspective of his bodily nature as "lacking the weapons of the other beings... But what is lacking in our nature, becomes a reason of superiority upon others." ${ }^{22}$ The perspective from which all these relations between man and other beings are viewed can constitute at any moment a perspective that can be defined today as balanced ecologism.

But the image itself, on the basis of that integrality of benefic attributes contained by it, can be for man a source of virtue, as I stated above, of virtuous potentiality, because

\begin{abstract}
"many and miscellaneous are the colors of the image that reflect the true shades of the original, in any case not the red or the white, or other medium color, but instead of these all, the purity, the freedom from sinful passions, the happiness, the deliverance from all the evil, and many others of this kind express man's creation in the likeness of God. You can see what flowers of His own image God used to adorn His creation, man.",23
\end{abstract}

The negative attributes prevail here because the presented shades of the image are of ethic nature, therefore they belong par excellence to the deliverance from evil, in relation to which the human being becomes positive by denying it. Therefore, all that is man's benefic orientation comes from the divine image. Man is again turned to good from this perspective that supposes his development according to the Archetype, to Jesus Christ, to the new Adam.

From all the features that make man the image of Archetype, there are two, that are not only correlated, but also of major importance in the oikonomia of humanity: freedom and love. If the first represents for man a summit of God's consideration towards the creature, and maybe, precisely due to its height it is also the riskiest, requesting of man to strung his entire will to head for the likeness, the second is the feature able to repair, on the one hand, from God to man, and on the other hand, from man to man and also to God: love. The same idea is expressed by Paul Evdokimov:

\begin{abstract}
"With Saint Gregory of Nyssa, man is related to God, deiform in his nature, which consecrates him for deification, the most intimate communion with God. While intelligence, wisdom and love are images of the same realities present in God, higher than all these, the power of self-determination is the one that comes to man from the divine image. The axiological function of reasoning, of appreciation, of judgment make man the king that rules over the nature, cosmic word participant to the divine life conditions. Between the deified man and God the difference is the following: the Divine is uncreated while man exists by creation." 24
\end{abstract}

Freedom is the most complexly appreciated in the work of Saint Gregory of Nyssa, first of all due to the binary potential it has: freedom is the complete likeness of God, and, simultaneously, its activation means the tragism of human nature. The structure of integrality

${ }^{22}$ Sf. Grigorie de Nyssa, Despre facerea omului, P.G. 44, 140D-141A

${ }^{23}$ Sf. Grigorie de Nyssa, Despre facerea omului, P.G. 44, 137 A-B

${ }^{24}$ Paul Evdokimov, La connaissance de Dieu selon la tradition orientale, Desclée de Brouwer, Paris 1988, p 33 
presumes as correlative quality of the divine image, moreover, as essential fundament of the personality, the gift of love. This because "God is love and also the source of love, as Great Saint John says that

\begin{abstract}
"Love is from God and that God is love. This was marked by the Creator of our nature on our face, because He says: By this everyone will know that you are My disciples, if you love one another. Hence, if this love does not exist, then all the image's features change. God sees all, hears all, and understands all. You also can understand what is going on, by seeing and hearing and the power of reasoning is the one that analyzes and understands everything." 25
\end{abstract}

In all the thinking of Saint Gregory of Nyssa we can observe the relevance of the entirety, the sense that presumes that not even one of the features should be thought of in isolation, as if not linked with the others. Just as reasoning without liberty falls apart, or justice without understanding loses itself as justice, similarly all the other features cannot really function, so they can not be in harmony with the nature they put into work in actions, if they are not correlated. But the fundamental feature, the one in which the thinking on the being of the divinity was conceived as having the maximum power of integration, the Good, that Good supposes love, and "has by its very nature the power to draw somehow to itself anyone looking for $i t^{\prime 26}$. Love in its turn determines man's action in agreement with his divine image, that action for which the very Oikonomia of the Son stands as a proof, as archetype of any Christian act.

\title{
CONCLUSION
}

Maybe the meeting between the Greek philosophy and the Christian theology has never been as harmonious as in the work of Saint Gregory of Nyssa. Maybe the Christian Revelation has never been so systematically structured, on the basis of Greek thinking, especially in ontology. All these, as we have seen, generated as well some divagations from what the Christian theology is nowadays, yet, beyond all these, remains this monument of theology, which, today, after seventeen centuries is relevant, however not yet discovered in its entire beauty, and, moreover, which shows us sometimes where we make mistakes in our own theological interpretations.

In Saint Gregory of Nyssa's theology, harmony is defining for the Holy Trinity, but, at the same time, it is a norm of the universe, it is a norm of the relation between man and universe, between man and the other people, and, in addition, is a norm precisely for man's structure, in which God set in perfect harmony the spirit of life and of reason together with the material of the world's elements. Harmony is the one that makes man be, beyond the appearances of a world continuously flowing; it is precisely harmony that makes man be a combination of elements, and, in the end, after the soul returns to God who gave it, harmony sends the elements to their places, then at the moment of the Resurrection, also under the sign of harmony, they will be unified, this time pneumatised, with the soul from which they had been separated by sin.

All these have only one Source: God, the One who edified man out of love and set him as a crown over his work, He Who like the Father from the evangelical parable, is waiting for us all as His prodigal sons. From here, the meaning that Saint Gregory of Nyssa disseminates in his entire work: man's entire destiny is connected, by creation, by Redemption and by Deification, to God. From here also comes the obsessive theme of

${ }^{25}$ Sf. Grigorie de Nyssa, Despre facerea omului, P.G. 44, 137C; P.S.B., vol 30, p 24

${ }^{26}$ Sf. Grigorie de Nyssa, Despre suflet şi înviere, P.G. 46, 89B; P.S.B. vol. 46, p 379 
reflection: man, as a reflection of Jesus Christ; Christ, as the Father's image, the Other, as an image of Christ, the very universe as image of the rational Logos, the spiritualized man as image of man according to his true nature, the ascendant approach as reflection in our own actions of the Way by which Christ has regained us for our Father.

\section{BIBLIOGRAPHY}

[1] Sfântul Grigorie de Nyssa, Dialog despre suflet şi înviere, P.G. 46, 60 A-B

[2] Hans Urs von Balthasar, Présence et Pensée - Essai sur la philosophie religieuse de Grégoire de Nysse, Beauchesne Editeur, Paris, 1988

[3] Sf. Grigorie de Nyssa, Despre facerea omului, P.G. 44, 133 A-B

[4] Panayotis Nellas, Omul - animal îndumnezeit, Editura Deisis, Sibiu, 1994

[5] A. G. Hamman, L'homme, image de Dieu, Desclée, Paris, 1987

[6] Alain Besançon, Imaginea interzisă, Editura Humanitas, Bucureşti, 1996

[7] Sfântul Grigorie de Nyssa, Marele Cuvant Catehetic, P.G. 45, 21 C

[8] Sfântul Grigorie de Nyssa, Despre feciorie, P.G. 46, 369B-376C

[9] Sfântul Grigorie de Nyssa, Despre Fericiri, P.G. 44, 1253D-1256A

[10] Paul Evdokimov, La connaissance de Dieu selon la tradition orientale, Desclée de Brouwer, Paris, 1988

[11] Berdiaev Nikolai, Împărăţia lui Dumnezeu si Împărăţia Cezarului, Editura Humanitas, Bucureşti 1998

[12] Kelly, N. D., Early Christian Doctrines, New York, 1978

[13] Lossky, Vladimir, Teologia Mistică a Bisericii de Răsărit, trad. pr. Răducă Vasile, Editura Anastasia, Bucureşti 1993

[14] Matsoukas, Nikos, Introducere în gnoseologia teologică, Editura Bizantină, Bucureşti, 2001

[15] Stăniloae, Preot Prof. Dr. Dumitru, Teologia Dogmatică Ortodoxă, vol. I, II, III, Editura Institutului Biblic şi de Misiune al Bisericii Ortodoxe Romane, Bucureşti 1997

[16] Thunberg, Lars, Omul şi cosmosul în viziunea Sfântului Maxim Mărturisitorul, Editura Institutului Biblic şi de Misiune al Bisericii Ortodoxe Române, Bucureşti, 1999 